\title{
Clinical, Histological, Immunohistochemical Aspects in a Rare Malignant Peripheral Nerve Sheath (Triton) Tumor
}

\author{
Laura REBEGEA ${ }^{1,2}$, Elena NICULET ${ }^{2}$, Mihaela CRAESCU ${ }^{1,3}$, Dorel FIRESCU ${ }^{4,5}$, Georgiana Bianca \\ CONSTANTIN ${ }^{4,5}$, Mihaela DUMITRU ${ }^{1}$, Cristina SERBAN ${ }^{4,5}$, Raul MIHAILOV ${ }^{4,5}$, Mihaela LUNGU 2,6
}

\begin{abstract}
Introduction: Immunohistochemistry is a widely used diagnostic technique in pathology, the antibodies used for unvailing a tissue's origin being made up of proteins, more specifically aminoacids. Malignant peripheral nerve sheath tumors have a distinct immunohistochemistry profile, with great emphasis concerning those with rhabdomyoblastic differentiation being positive for S-100 protein, myogenin, vimentin, CD99, p63, GFAP, caldesmon, desmin, and p53 and Myo-D1 (the later two revealing the striated muscle differentiation). Materials and methods: A case study concerning a patient suffering from a moderately differentiated (G2) non-keratinizing squamous cell carcinoma of the lung highlighted the development of an undifferentiated sarcomatous proliferation on the left hemithorax, 7 years after the initial external radiotherapy treatment for the malignant lung tumor. Results: The immunohistochemistry analysis of the thoracic wall invasive tumor revealed it to be a malignant peripheal nerve sheath tumor with rhabdomyoblastic differentiation (Triton tumor) with the positivity for the specific aforementioned markers and a proliferation index - Ki67 of 90\%. Chemotherapy was the elective treatment which was followed for 1 month, the patient having a rapid downward evolution towards exitus, with a 33 month post-diagnosis survival. Conclusions: This case was presented due to the rarity and difficulty of the diagnosis, consisting of a rare subtype of malignant peripheral nerve sheath tumor for which there is no therapeutic consensus and with an un-favorable prognosis.
\end{abstract}

Keywords: immunohistochemistry, marker of proliferation, Triton tumor.

\section{Rezumat}

Introducere: Imunohistochimia reprezintă o metodă de diagnostic larg utilizată în patologie, anticorpii utilizați pentru depistarea originii celulare au structură proteică, mai exact de aminoacizi. Tumorile maligne de teacă de nerv periferic au un profil imunohistochimic distinct, reprezentând o varietate de tumoră cu diferențiere rabdomioblastică, fiind pozitive pentru proteina S-100, miogenină, vimentină, CD99, p63, GFAP, caldesmon, desmina, p53 si Myo-D1 (ultimele două indicând diferențierea musculaturii striate). Material și metodă: Prezentăm cazul unui pacient diagnosticat cu neoplasm pulmonar stâng, cu histologie de carcinom scuamos necheratinizat, moderat diferențiat, pentru care s-a practicat intervenție chirurgicală și radioterapie. Examenul computer tomograf efectuat la 7 ani de la tratamentul inițial identifică masă tumorală în hemitoracele stâng care invadează mușchiul pectoral cu histologie

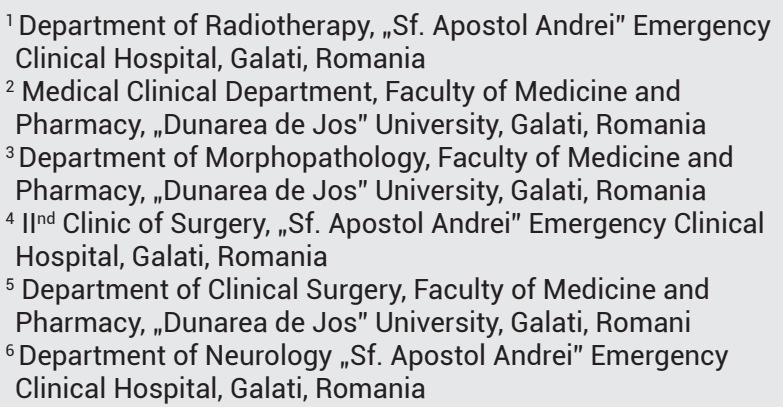

\section{Corresponding author:}

Laura REBEGEA, Department of Radiotherapy, "Sf. Apostol Andrei” Emergency Clinical Hospital, Galati, Romania.

E-mail: laura_rebegea@yahoo.com 
de proliferare sarcomatoasă nediferențiată, posibil tumoră malignă de teacă de nerv periferic. Rezultate: Testele de imunohistochimie pentru masă tumorală din peretele toracic au confirmat tumora malignă de teacă de nerv periferic cu diferențiere rabdomioblastică (tumora Triton) cu valori pozitive ale markerilor menționați anterior și Ki67 + 90\%. Pacientul urmează chimioterapie, 6 cure; complianță bună la tratament fără toxicități secundare, biologic, se decelează și hepatita cu virus C. Ulterior evoluția pacientului este nefavorabilă și decedează după o perioadă de urmărire de 33 de luni. Concluzii: Prezentăm acest caz datorită rarității și dificultăților de diagnostic și tratament. Tumora malignă de teacă de nerv periferic reprezintă un subtip histologic rar, pentru care nu există un consens terapeutic și care prezintă un prognostic nefavorabil.

Cuvinte cheie: imunohistochimie, marker de proliferare, tumora Triton.

\section{INTRODUCTION}

Immunohistochemistry (and immunocytochemistry, for cell preparations) is a technique used by pathologists worldwide in order to positively identify tissue (or cell) constituents, more specifically antigens, with the help of certain antibodies which can be observed through staining. The latter are in fact proteins, chemically made up of amino acids. The histological origin and the function of the cell are revealed through this special staining, a highly useful tool in tumor diagnosis, especially in those cases of undifferentiated tumors. Immunohistochemistry analysis comes to support the morphological diagnosis in the case of malignant Triton tumors, aiding in establishing the correct diagnosis. The immunohistochemistry profile of Triton tumors consists of positivity for S-100 protein, myogenin, vimentin, CD99, p63, GFAP, caldesmon, desmin, and p53 and Myo-D1, the last two revealing striated muscle differentiation; $\mathrm{Ki}-67$ is usually highly expressed.

$\mathrm{Ki}-67$ is an antigen first found in the nuclei of Hodgkin lymphoma cycling cells, becoming an important proliferation marker in many types of cancers and having important prognostic value. It is a nuclear-binding protein with two isoforms having complex chemical formulas ${ }^{1-6}$.

Malignant peripheral nerve sheath tumors represent $5 \%$ to $10 \%$ of soft tissue sarcomas; when they acquire rhabdomyoblastic differentiation they are called Triton tumors and were first described in the literature data in 1938 by Masson and Martin ${ }^{7}$. Woodruff et al. ${ }^{8}$ named Triton, for the first time, on the basis of the discovery that supernumerary limbs containing neural and muscular elements that were induced to grow on the backs of triton salamanders by transplantation. Triton tumors have an aggressive behavior and are frequently located in the cephalic extremity, neck region, extremities and trunk; rare locations for these malignant proliferations are the mediastinum and retro peritoneum.

\section{CASE PRESENTATION}

We present the case of a 66 years-old patient with no significant family or personal history, which was diagnosed in June 2009 with a left side malignant lung tumor $(\mathrm{T} 2 \mathrm{NxMx})$.

The surgical approach consisted of a left pneumonectomy associated with mediastinal lymphadenectomy and was carried out in "Prof. Dr. Al. Trestioreanu” Oncological Institute of Bucharest (IOB); it was followed by the histopathological examination (HP) of the surgical resection piece and the diagnosis of moderately differentiated (G2) non-keratinized squamous cell carcinoma was established.

In the postoperative period adjuvant chemotherapy was administered and in September 2009 the patient started external radiotherapy (RTE) treatment with Co60 using 2D technique and having a total dose (TD) of $50 \mathrm{~Gy} / 25 \mathrm{fr} / 35$ days, with $\mathrm{D} / \mathrm{fr}$. of $200 \mathrm{cGy} /$ tumor bed and TD of $40 \mathrm{~Gy}$ on planning target volume (PTV) - mediastinal region at the "Sf. Ap. Andrei" Emergency Clinical Hospital of Galati.

Stage assessment was done consisting of a computed tomography scan (CT) and skeletal scintigraphy and no secondary lesions were found.

In November 2016 the patient became symptomatic and addressed the surgical department of the IOB for the development of a tumor located on the anterior superior left thoracic wall. A thoraco-abdominal CT scan was done revealing a tumor mass which extended along the anterior and superior regions of the left hemithorax and invaded the pectoral muscle and the first, second and third anterior left ribs. The CT scan also found a left pleurisy with accumulation of a large quantity of liquid and multiple anterior pleural iodophilic tumor masses without thoracic or axillary lymph node enlargement; no other lesions of extrapulmonary oncological interest were found. 
A decision to biopsy the parietal tumor was made and it revealed an undifferentiated sarcomatous proliferation, with the presumption of being a malignant peripheral nerve sheath tumor (MPNST).

The multidisciplinary commission recommended chemotherapy treatment which consisted of 6 courses with doxorubicin $130 \mathrm{mg}$, according to protocol (80 $\mathrm{mg} / \mathrm{m}^{2}$ ). The patient had a good compliance to treatment without any secondary toxicity; laboratory findings detected a hepatitis $\mathrm{C}$ virus infection.

In May 2017 the patient performed a positron emission tomography (PET/CT) scan which detected a left thoracic wall residual tumor with some regions of metabolic activity, SUV 6.21 (Figure 1).

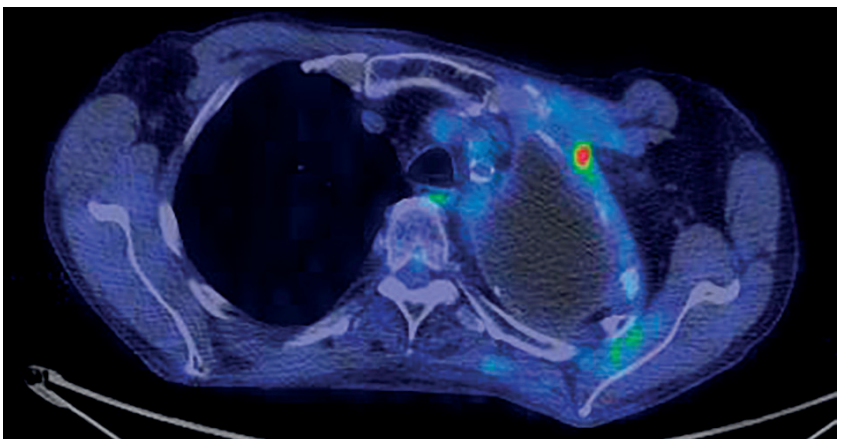

Figure 1. PET CT scan. Residual tumor with some regions of metabolic activity

A second opinion immunohistochemistry examination was done and based on morphological and immunohistochemistry profile a positive diagnosis of malignant Triton tumor (malignant peripheral nerve sheath tumor with a striated muscle component) of high grade (G3 - poorly differentiated, corresponding to a score of 7 as established by the French Federation of Cancer Centers Sarcoma Group (FNCLCC) system); the malignant proliferation had no lymphovascular (LV0) or perineural invasion $(\mathrm{Pn} 0)$. The immunophenotype registered positivity for vimentin, S100, GFAP, caldesmon, desmin, myogenin and $\mathrm{p} 53$, with a high proliferation rate - Ki 67 of 90\% (Fig. 2); the negative markers were pancytokeratin and $\mathrm{p} 16$. The pathology report for the lung carcinoma reported it as a moderately differentiated (G2) squamous cell carcinoma with lymphovascular invasion (LV1) and indeterminate perineural invasion $(\mathrm{PnX})$. The immunophenotype presented positivity for p63, p53 and a high proliferation index (Ki67) of 80\%; the malignancy was negative for TTF1 and presented an equivocal EGFR status with a score of $2+$.

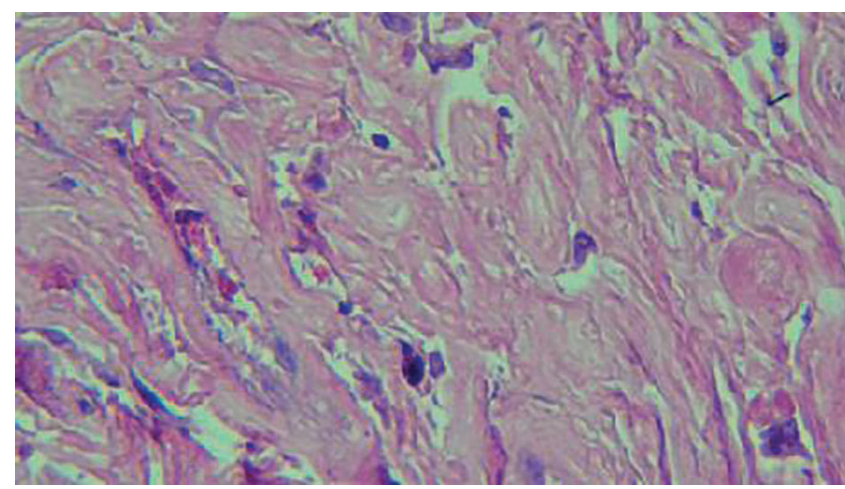

Figure 2. Triton tumor - a. hypocellular area with variable nuclear morphology (wavy, slender or "comma-shaped”) (H\&E, 400x).

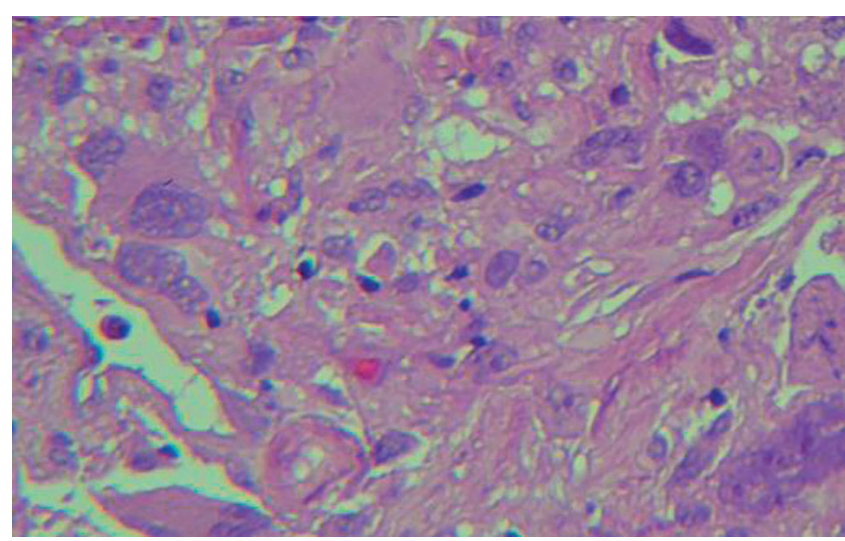

Figure 3. Triton tumor $-b$. hypercellular area with perivascular concentration of malignant cells. (H\&E, 400x)

The malignant peripheral nerve sheath tumor was confirmed on the basis of morpho-pathological examination and relevant immunohistochemistry profile; thus, the most important histopathological aspects which support this diagnosis are: alternation of hypoand hypercellular areas, slim, windy or comma-shaped nuclei (mostly found in hypocellular areas), marked cellular pleomorphism, perivascular crowding of cells, nuclear palisading, tactoid bodies, thick walled blood vessels and the presence of heterologous elements (striated muscle, cartilage or bone tissues).

Rhabdomyosarcomatous differentiation (striated muscle tissue) of this tumor gives it the name Triton tumor and is characterized microscopically by the presence of malignant rhabdomyoblastic (large cells with an eccentric nucleus and intensely eosinophilic cytoplasm which sometimes can have cross striations).

Triton tumor's immunohistochemistry profile is characterized by the positivity of the following markers: vimentin, S100, CD99, p63, GFAP, caldesmon, desmin, myogenin and $\mathrm{p} 53$. The cellular proliferation 
marker - Ki67 is positive in over $90 \%$ of cells, highlighting the aggressive behavior of the malignant tumor. Positive muscular differentiation markers - desmin and myogenin, confirms the heterologous, striated muscle differentiation of some of the neoplastic cells, confirming the diagnosis of Triton tumor ${ }^{4-6}$.

From May 2017 until December 2018, the biological and imaging assessments show no further evolvement, the patient's status being stationary. As of March 2019, the patient became symptomatic with significant weight loss, left upper motor limb dysfunction and pain which could be managed with major analgesic treatment.

Following a CT scan examination done in April 2019, a tumor mass in the anterior lateral and apical left thoracic wall is found, which was highly invasive and with moderately heterogeneous iodophillia. It presented clear progression with enlargement and extension to the subclavicular and axillary subcutaneous regions, while associating multiple local and regional adenopathies with maximum dimensions of 23/17 $\mathrm{mm}$. The scan also revealed newly developed multiple secondary small nodular lesions in the right inferior lung lobe with maximum measurements of 20/16 mm.

In this context the decision to perform palliative RTE is made, located at chest wall level, with a TD of 30Gy/10fr /14 days, using a 2D technique. Treatment with TKI, respectively Pazopanib (800 mg/day) for 1 month is attempted, but the patient died August 2019 with a survival rate of 33 months from the moment the diagnosis was made.

\section{DISCUSSIONS}

Woodruff et al. ${ }^{8,9}$ also proposed three criteria for determining whether a neoplasm could be truly classified as a malignant 'Triton' tumor or not: one, arises from a peripheral nerve, or in a patient with NF-1, or in a location typical for peripheral nerve tumors, or represents a metastasis from such tumor; two, demonstrates the growth characteristics of Schwann cells; and three contains bona fide rhabdomyoblasts that appear to arise from within the body of the peripheral nerve tumor and which cannot be attributed to either an extension or metastasis from an extrinsic rhabdomyosarcoma.

From an epidemiological point of view MTT is found under the following aspects: in 70\% of cases it exists in combination with neurofibromatosis type 1 $(\mathrm{NF}-1)$, predominantly in young male patients, while
$20 \%$ of cases are sporadic. MTT may also occur after radiotherapy treatment. Sporadic types are frequently seen in elderly women ${ }^{10}$. In this case study, the malignant tumor did not develop on the background of neurofibromatosis, the 66 years old male patient presenting a history of external radiation.

MTT is a clinically evident, painful or painless tumor, occurring in various areas such as the head and neck region, the extremities, trunk, retroperitoneum, mediastinum or intracranial; it may affect nerve structures such as the sciatic, brachial plexus, lumbar, sacral or even cranial nerves. In the case presented, the patient's illness started with a painful tumor located in left anterior hemithorax.

Clinical signs are not specific for this neoplasm and histopathology combined with immunohistochemistry (IHC) remain the standard investigations in establishing the diagnosis of MTT.

The 2 distinct metachronous neoplasms were suggest by IHC performed on both tumors - lung neoplasm and thoracic wall. The first neoplastic process was characterized by a moderately differentiated (G2) squamous cell lung carcinoma with lymphovascular invasion (LV1) and indeterminate perineural invasion ( $\mathrm{PnX}$ ). The immunophenotype of this tumor was: p63 and p53 (+) with TTF1 (-) and an overall Ki67 index of $80 \%$. The EGFR expression status was equivocal, having a score of 2+. The second neoplastic process found on anterior left thoracic wall, is extremely rare and usually is found in the context of a germline mutation in the NF1 gene. Mutations in the TP53 gene are exceptional phenomena in this type of sarcoma, and the similar aspect encountered in the lung tumor mass requires the exclusion of a germline mutation of TP53 to be done. This malignancy can be evaluated in the context of radiotherapy treatment performed as of 2009 for lung cancer.

The important prognostic factors are tumor location (with better prognosis for those in the head and neck, trunk or limbs), surgical resection margins extension, high degree of differentiation, increased Ki67 expression and radiation exposure; the last three listed are unfavorable prognostic factors.

According to a retrospective study done by Aldlyam et al., performed on 9 cases, we drew the conclusion that MTTs are tumors with an unfavorable prognosis, having a 5 years survival rate of only 5 to $15 \%$, in direct contrast to MPNST where survival is cited as having a rate of 50 to $60 \%{ }^{11,12}$.

The treatment was a conventional multidisciplinary approach and consisted of radical tumor excision fol- 
lowed by high dose radiotherapy. Some recent reports suggest that neoadjuvant therapy and adjuvant chemotherapy can eradicate micro-metastases and increase overall survival ${ }^{13,14}$.

In the present case, MTT developed 8 years after the first radiotherapy session and the survival registered from the time of the first neoplastic process site was of 10 years.

Also, in this case, multidisciplinary team had an important role to support the patient, in order to better understanding of disease itself, side effects, disease relapsing, changing treatment sequences and palliative care ${ }^{15}$.

Malignant triton tumors are uncommon sarcomas that are associated with a high incidence of local recurrence and distant metastases.

Malignant tumor triton are extremely rare soft tissue sarcomas that are frequently associated with neurofibromatosis type 1 (NF1) are associated with a high incidence of local recurrence and distant metas- tases. Immunohistochemistry is an essential tool for the correct diagnosis. Radical surgery excision is recommended as election treatment whenever possible. Chemotherapy and radiotherapy are treatments suggested by different authors for increased survival.

We presented this case due to the rarity and difficulty of the diagnosis, consisting of a rare subtype of malignant peripheral nerve sheath tumor for which there is no therapeutic consensus and with an unfavorable prognosis.

Compliance with ethics requirements: The authors declare no conflict of interest regarding this article. The authors declare that all the procedures and experiments of this study respect the ethical standards in the Helsinki Declaration of 1975, as revised in 2008(5), as well as the national law. Informed consent was obtained from all the patients included in the study.

\section{References}

1. Shetty PK, Baliga SV, Balaiah K. Malignant triton tumor: a rare case. Indian J Surg. 2013; 75(Suppl 1):362-365.

2. Matos LL, Trufelli DC, De Matos MG, Da Silva Pinhal MA Immunohistochemistry as an important tool in biomarkers detection and clinical practice. Biomark Insights 2010;5:9-20.

3. Sun X, Kaufman PD. Ki-67: more than a proliferation marker Chromosoma 2018;127(2):175-186.

4. Shete S, Bolde S, Pandit G, Matkari P, Ingle SB. Unusual histological variant of malignant peripheral nerve sheath tumor with rhabdomyoblastic differentiation. World J Clin Cases 2015;3(4): 389-392.

5. Tripathy K, Mallik R, Mishra A, Misra D, Rout N et al. A rare malignant Triton tumor. Case Rep Neurol 2010;2(2):69-73.

6. Bishop JA, Thompson LDR, Cardesa A, Barnes L, Lewis Jr JS et al. Rhabdomyoblastic differentiation in head and neck malignancies other than rhabdomyosarcoma. Head Neck Pathol 2015;9(4): 507-18.

7. Masson P. Recklinghausen's neurofibromatosis. Sensory neuromas and motor neuromas. In Libman Anniversary, volume 2, NY, New York: The International Press, 1932:793-802.

8. Woodruff JM, Chernik NL, Smith MC, Millett WB, Foote FW Peripheral nerve tumors with rhabdomyosarcomatous differentiation (malignant "Triton" tumors). Cancer 1973;32:426-439.

9. Li Z, Xiang J, Yan S, Gao F, Zheng S. Malignant triton tumor of the retroperitoneum: a case report and review of the literature. World J Surg Oncol 2012;10: 96.

10. Zisis C, Fragoulis S, Rontogianni D, Stratakos G, Bellenis I. Malignant triton tumour of the anterior mediastinum as incidental finding. Monaldi Arch Chest Dis 2006;65(4):222-224.

11. Brooks JS, Freeman M, Enterline HT. Malignant triton tumors: Natural history and immunohistochemistry of nine new cases with literature review. Cancer 1985;55:2543-2549.

12. Aldlyami E, Dramis A, Grimer RJ, Abudu A, Carter SR et al. Malignant triton tumor of the thigh - a retrospective analysis of nine cases. Eur J Surg Oncol 2006; 32: 808-810.

13. Kudo M, Matsumoto $\mathrm{M}$, Terao $\mathrm{H}$. Malignant nerve sheath tumor of acoustic nerve. Ach Pathol Lab Med 1983; 107: 293-297.

14. Grimer R, Judson I, Peake D, Seddon B. Guidelines for the management of soft tissue sarcomas. Sarcoma 2010: 506182.

15. Rebegea L, Firescu D, Baciu G, Ciubara A. Psycho-Oncology Support. Brain 2019;10(3):77-88. 